\title{
Spatial pattern quantification of Antarctic benthic communities using landscape indices
}

\author{
N. Teixidó ${ }^{1, *}$, J. Garrabou ${ }^{2}$, W. E. Arntz ${ }^{1}$ \\ ${ }^{1}$ Alfred Wegener Institut für Polar- und Meeresforschung, Columbusstraße, 27568 Bremerhaven, Germany \\ ${ }^{2}$ Station Marine d'Endoume, Centre d'Oceanologie de Marseille Station Marine d'Endoume, rue Batterie des Lions, \\ 13007 Marseille, France
}

\begin{abstract}
Antarctic benthos exhibits highly complex communities showing a wide array of spatial patterns at several scales which are poorly quantified. In this study, we introduce the use of methods borrowed from landscape ecology to study quantitatively spatial patterns in the Antarctic megaepibenthic communities. This discipline focuses on the notion that communities can be observed as a patch mosaic at any scale. From this perspective we investigated spatial patterns in an Antartcic benthic assemblage across different stations based on landscape indices, and we chose the optimal subset for describing Antarctic benthic patterns. For this purpose, 42 photographs $\left(1 \mathrm{~m}^{2}\right.$ each) corresponding to 6 stations from the Weddell Sea shelf were investigated. Canonical variate analysis (CVA) showed the arrangement of photographic records along a patch size and diversity gradient on the first axis and a heterogeneity pattern gradient (cover area, interspersion and juxtaposition, landscape shape indices) on the second axis. Based on a forward stepwise selection, mean patch size (MPS), patch size coefficient of deviation (PSCV), patch richness (PR), interspersion and juxtaposition index (IJI), mean shape index (MSI), Shannon's evenness (SHEI), and periarea index (PERIAREA) were chosen as the adequate subset of indices to describe the Antarctic benthos. Principal Component Analysis (PCA) was used to identify relationships among them. The resulting 3 factors were interpreted as (1) a heterogeneity pattern (related to patch size, form, diversity, and interspersion indices), (2) an equitability pattern (represented by the evenness index), and (3) a perimeter-area pattern (characterised by the periarea index). Analysis of variance (ANOVA) was carried out to detect differences among the stations based on the subset of indices. Overall, the results showed large differences in patch characteristics (mean and its coefficient of variation, and shape indices), diversity, and interspersion. The successful description of Antarctic benthic communities through landscape pattern indices provides a useful tool for the characterisation and comparison of spatial patterns in these diverse marine benthic habitats, which gives insights in their organisation.
\end{abstract}

KEY WORDS: Antarctic · Benthic communities $\cdot$ Landscape indices $\cdot$ Multivariate ordination $\cdot$ Underwater photographs $\cdot$ GIS

Resale or republication not permitted without written consent of the publisher

\section{INTRODUCTION}

During the last decades considerable research has been carried out on Antarctic benthic communities, mainly related to aspects of systematics, zoogeography, reproduction, and foraging biology (Dayton 1990, Arntz et al. 1994, Gutt 2000). Studies on patterns and

*E-mail: nteixido@awi-bremerhaven.de processes in benthic Antarctic communities are of general interest to understand their development, to describe their structure and to characterise their function (Hedgpeth 1971, Dell 1972, White 1984, Arntz et al. 1994, Clarke 1996).

Communities generally exhibit heterogeneity and patchiness on a broad range of scales. Understanding patterns in terms of scale is of fundamental interest in terrestrial and marine ecology (Levin 1992). Largescale biogeographic patterns of the Antarctic macro- 
benthos have been extensively described using traditional sampling techniques (e.g. dredges, grabs, and trawls) (Knox 1960, Bullivant 1967, Hedgpeth 1969, Dell 1972, Arnaud 1977, Sarà et al. 1992). Recently, observations by remote underwater photographs, ROV (remotely operated vehicle) supported video records, and SCUBA diving have been supplemented to studies at intermediate and finer scale. These studies focused mainly on the distribution, structure, and vertical zonation of Antarctic benthos (Gruzov et al. 1968, Hedgpeth 1969, Dayton et al. 1970, Arnaud 1974, Kirkwood \& Burton 1988, Gambi et al. 1994, Barnes 1995, Gutt \& Starmans 1998, Starmans et al. 1999).

The use of modern imaging techniques provides a view of non-destroyed benthic community structure with high resolution over large areas. Nevertheless, there still is a paucity of analytical methods to obtain ecologically relevant data from images. As a consequence, the general aim of this study is to introduce landscape pattern indices as a new tool to analyse Antarctic benthic community images and to improve our understanding of spatial patterns in these communities, in particular, and of marine habitats in general (Garrabou et al. 1998, Garrabou et al. in press).

Landscape ecology has developed rapidly over the last 10 yr (Forman \& Gordon 1986, Turner 1989). The driving force lies in the need to tackle ecological problems (e.g. global climatic change, deforestation) on a broad range of spatial-temporal scales (Turner 1989). In recent years landscape ecologists have concentrated their efforts on the development of a large collection of indices to describe dynamics and patterns of landscapes (e.g. O'Niell et al. 1988; Turner 1989, Kineast 1993, Wiens et al. 1993, Riitters et al. 1995). These indices have been applied successfully at many spatialtemporal scales, ranging from a broad scale $(\mathrm{km})(\mathrm{e} . \mathrm{g}$. O'Niell et al. 1988, Turner \& Ruscher 1988, Kineast 1993, Hulshoff 1995, McGarrigal \& McComb 1995, Ritters et al. 1995, Drapeau et al. 2000) to a finer scale ( $\mathrm{m}$ and $\mathrm{cm}$ ) (Garrabou et al. 1998, Saunders et al. 1998).

However, the large number of landscape metrics used to quantify landscape patterns and structure provides redundant information (O'Niell et al. 1988, Riitters et al. 1995, Hargis \& Bissonette 1998). Different procedures of multivariate analysis have been applied to reduce the large amount of information to a smaller set of indices (Riitters et al. 1995, Cain et al. 1997). There is, however, not an ideal standard subset of indices to describe terrestrial patterns, nor is there one to describe benthic marine habitats.

In this study, we investigated the Antarctic benthos spatial patterns at a fine scale $(1 \mathrm{~m})$ through the application of landscape pattern indices (LPI). We considered $1 \mathrm{~m}^{2}$ as the appropriate scale of observation for both image resolution and sampling area obtained.
The indices quantify spatial patterns assuming that benthic communities can be observed as patch mosaics, where patches are associated to different categories (e.g. species). From this perspective, community spatial patterns and dynamics can be analysed by focusing on the characteristics of the patch mosaics.

The objectives of this study were: (1) to apply landscape pattern indices to characterise quantitatively, at a finer scale, spatial patterns in an Antarctic benthic assemblage across different stations, and (2) to choose a subset of landscape pattern indices which is the best suited for describing benthic patterns.

\section{MATERIALS AND METHODS}

Study area and benthic communities. The Antarctic continent is largely covered with ice, which at some places extends from the continent into the sea forming the ice shelves (Knox 1994). The continental shelf in the southeastern Weddell Sea is relatively narrow (less than $90 \mathrm{~km}$ ) and ranges to a depth of $500 \mathrm{~m}$ (Carmack \& Foster 1977, Hempel 1985). Kapp Norvegia is located in the eastern Weddell Sea (Fig. 1), where the shelf undergoes seasonal pack-ice coverage (Tréguer \& Jacques 1992) and where, especially during summer, coastal polynyas of varying size occur (Hempel 1985). Water temperature close to the sea bottom is low and relatively constant, ranging from -1.3 to $-2.0^{\circ} \mathrm{C}$ (Fahrbach et al. 1992). There is a marked seasonal variation in primary production, mostly confined to summertime under the sea ice and in open water (Nelson et al. 1989, Gleitz et al. 1994, Park et al. 1999). The organic matter flux from surface waters to the seabed through the water column shows temporal variation, e.g. with high values after a sinking bloom of diatoms in summer (Bathmann et al. 1991, Gleitz et al. 1994). Hydrodynamics do not only affect the food availability from the water column but also determine the sediment characteristics (e.g. grain size and composition), which are of ecological relevance for benthic communities (Dunbar et al. 1985, Gutt 2000). Iceberg scouring dramatically disturbs benthic communities at certain depths on the continental shelf, mainly between 150 and $300 \mathrm{~m}$ (Gutt et al. 1996, Peck et al. 1999).

Antarctic benthic communities have been described as 'multistoried assemblages', meaning the epibiotic relationship between species, which serve as a substratum for other species (Knox \& Lowry 1977, Gutt \& Schickan 1998 and citations therein). The benthos of the Antarctic continental shelf and slope in the eastern Weddell Sea is generally known as an ecosystem with intermediate to high species richness (Starmans \& Gutt 2002), locally extreme high epifaunal biomass with up to $1.67 \mathrm{~kg} \mathrm{~m}^{-2}$ wet weight (Gerdes et al. 1992), and 


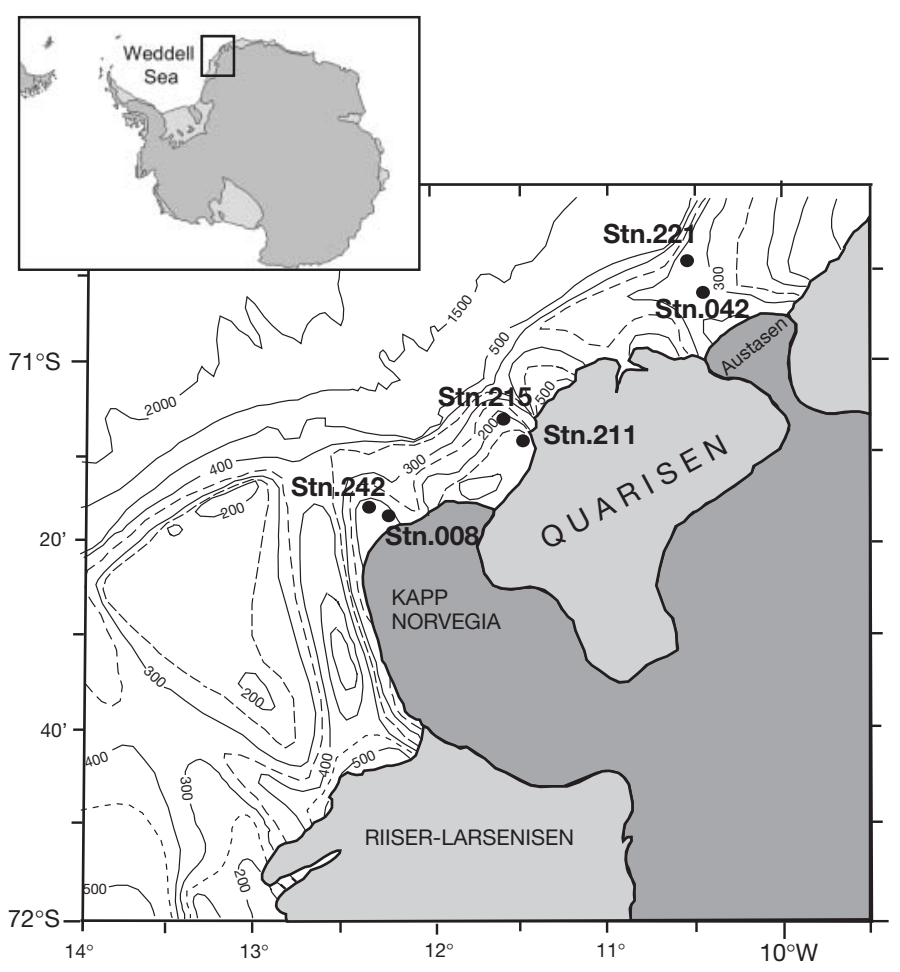

Fig. 1. Study area in the southeastern Weddell Sea (Antarctica) showing the location of photographic stations and their depths: Stn 008 (171 m), Stn 042 (251 m), Stn 211 (117 m), Stn $215(160 \mathrm{~m})$, Stn 221 (265 m), and Stn 242 (159 m). (Subsection of chart AWI BCWS 553)

patchy distribution (Starmans et al. 1999). The Kapp Norvegia region belongs to the Eastern Shelf Community described by Voß (1988) as the richest high Antarctic community. The fauna in this area is dominated by sessile suspension feeders, e.g. sponges, gorgonians, bryozoans, and ascidians, which locally cover the sediment completely (Gutt \& Starmans 1998, Starmans et al. 1999). In some areas off Kapp Norvegia the benthos can be dominated by sponges, e.g. the hexactinellids Rossella racovitzae, $R$. antarctica, $R$. nuda, and the demosponge Chinachyra barbata.

Photosampling. Photographic records of the seafloor were obtained from expeditions ANT XIII/3 and ANT XV/3 on board RV 'Polarstern' during the austral summers of 1996 and 1998 (Arntz \& Gutt 1997, 1999). This research was performed within the EASIZ (Ecology of the Antarctic Sea Ice Zone) frame as a part of a SCAR (Scientific Committee on Antarctic Research) programme. A $70 \mathrm{~mm}$ underwater camera (Photosea 70) with 2 oblique strobe lights (Photosea 3000 SX) was triggered at a fixed distance $(1.4 \mathrm{~m})$ from the seafloor by a bottom contact switch while the ship drifted (Gutt \& Starmans 1998). This device can obtain perpendicular photographs of the sea bottom at a constant height above it. The optical resolution is around $0.3 \mathrm{~mm}$. At each station a series of 80 pictures (Kodak Ektachrome 64) were taken at evenly spaced time intervals along a transect. Each one covered approximately $1 \mathrm{~m}^{2}$. Six stations were chosen (depth range: 165 to $265 \mathrm{~m}$ ) on the continental shelf off Kapp Norvegia (Fig. 1). At each station 7 photographs, which encompassed different scenarios of the 'undisturbed assemblage' previously defined by Gutt \& Starmans (2001), were studied and processed. They represent different benthic views according to species composition variability. A total of 42 seafloor photographs was analysed representing an area of $42 \mathrm{~m}^{2}$.

Image analysis. Each photograph was projected on an inverse slide projector and all distinguishable patch outlines were traced onto an acetate sheet (Garrabou et al. 1998). The drawings were scanned at 100 dpi resolution. The resulting raster images (TIFF format) were imported into a public domain image application $\mathrm{NIH}$ Image (U.S. National Institutes of Health, Version 1.61; http://rsb.info.nih.gov/nih-image), where they were subjected to different technical procedures (converted into black and white and the lines were thinned to unit width). Then, the images were imported into Arc/View 3.2 (ESRI) geographical information system (GIS) where they were spatially referenced. Arc/View routine procedures were used to label all the patches (e.g. cover categories). After these processes the images were converted to Arc/Info vector data format for further calculations using the Arc/Info 8.1 program (ESRI) (Fig. 2).

Photo identification. Megaepibenthic sessile organisms (approx. $>0.5 \mathrm{~cm}$ body size diameter that live on the seabed) visible in photographs were identified to the lowest possible taxonomic level by referring to the literature (Thompson \& Murray 1880 to 1889, Discovery Committee Colonial Office 1929 to 1980, Monniot \& Monniot 1983, Sieg \& Wägele 1990, Hayward 1995) and by the assistance of taxonomic experts (see 'Acknowledgements').

We recognized a total of 138 sessile cover categories. These included species/genus (123), phylum (3), 'complex' (7), and substratum (5). Within the species/genus category, some unidentified sponges (e.g. 'yellow branches') were named according to Barthel \& Gutt (1992). Irregular masses composed by matrices of bryozoans together with demosponges and gorgonians of small size and similar filamentous morphology were assigned to one of the 7 'complex' cover classes.

The benthos in the Weddell Sea locally presents different stratum levels of organisms. The images analysed may underestimate the contribution of the basal stratum to the epibenthic assemblage. However, we decided to use $2 \mathrm{D}$ seabed images to quantify spatial patterns in Antarctic benthic communities because they retain most of the spatial pattern characteristics. 
A)

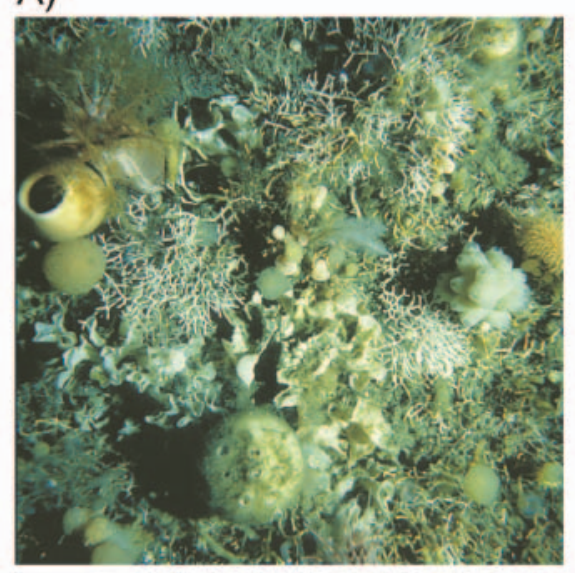

\section{Underwater photographs}

B)

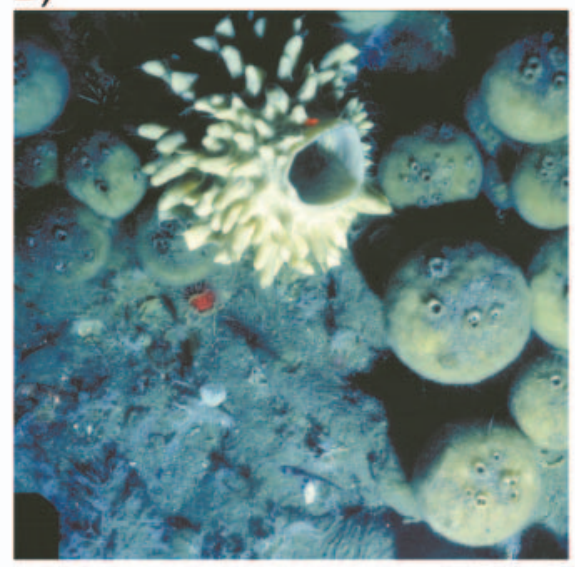

C)

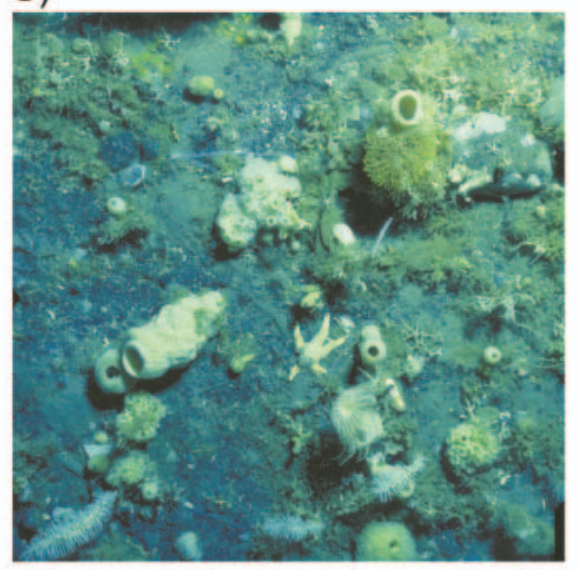

Image transformation

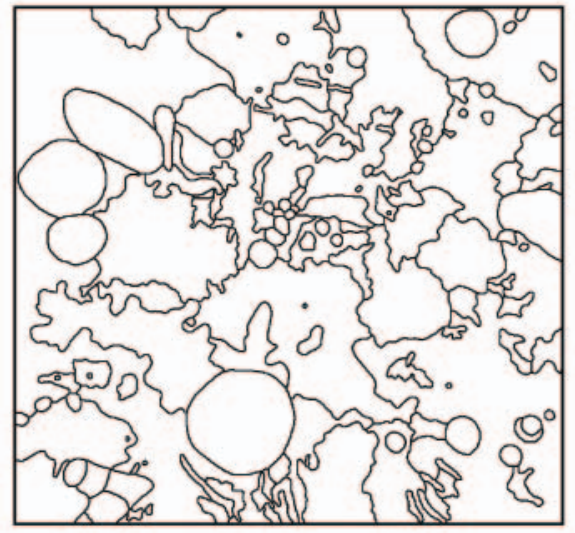

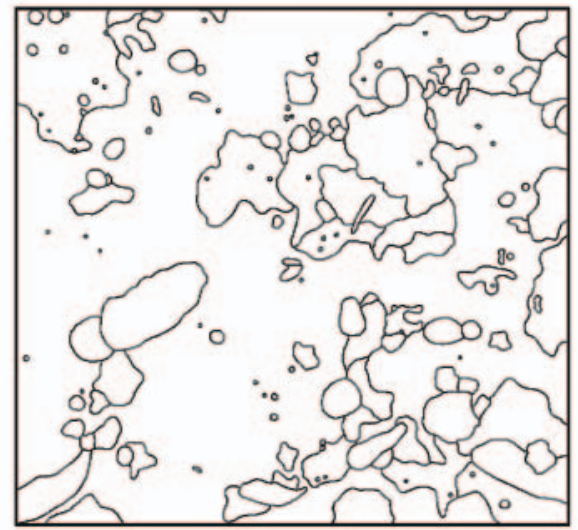

Image analysis
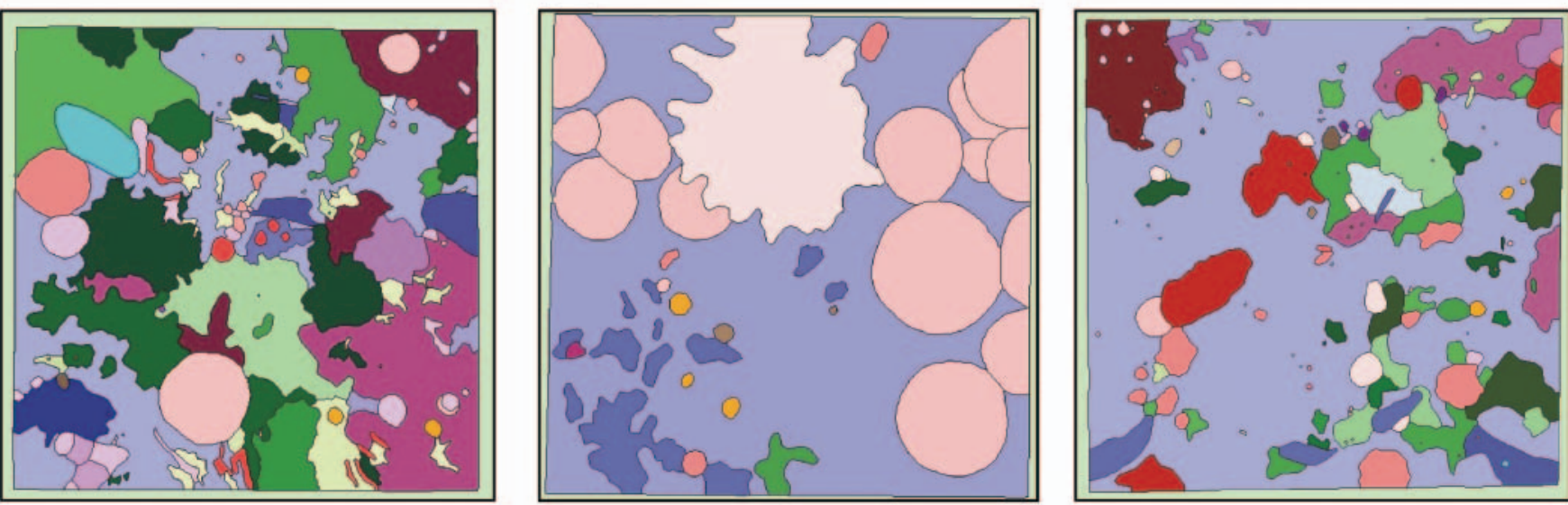

Fig. 2. Underwater photographs: undisturbed Antarctic benthic assemblage: (A) dominated by different groups of benthic suspension feeders (e.g. sponges, gorgonians, bryozoans, and compound ascidians; Stn 008), (B) composed mainly of sponges (Rossella sp., Cinachyra barbata; Stn 211), and (C) characterised by demosponges, gorgonians, and bryozoans, which partially cover the seafloor; Stn 221). Image transformation: the drawings were scanned and submitted to different technical processes (see text). Image analysis: the images were imported into Arc/View 3.2 where they were georeferenced and labeled. Finally, the images were transformed to vector coverage data to calculate landscape pattern indices (LPI) using the program Fragstats v3.0 for Arc/Info. Underwater photographs: J. Gutt, D. Piepenburg 
Landscape pattern indices (LPI). LPI were calculated for each image by using the spatial pattern program Fragstats v3.0 for Arc/Info (Pacific Meridian Resources). Fragstats calculates landscape indices separately for (1) patch (basic elements of the mosaic), (2) class (each particular patch type), and (3) landscape (mosaic of patches as a complete unit) levels. A total set of 17 indices concerning distinct aspects of spatial patterns were calculated at landscape level (Table 1). For more information about these indices (descriptions, mathematical equations, and examples) see McGarrigal \& Marks (1995).

Statistical analysis. As an initial step, multivariate ordination techniques were used to identify spatial pattern relationships within a benthic assemblage across different stations from the southeastern Weddell
Sea. Such methods arrange multidimensional data (e.g. stations, species) along axes (or dimensions) on the basis of variables (e.g. landscape indices, environmental variables). Canonical variate analysis (CVA) was conducted on the LPI data matrix to provide a representation of the photographic stations on the ordination diagram. Data for CVA typically consist of measurements (n) on variables (m). Each of the measurements is associated with an object belonging to one of predefined groups $(\mathrm{g})$. The standardized coefficients of the canonical axes indicate the relative contributions of the original variables to each axis (Legendre \& Legendre 1998). CVA was considered an adequate multivariate technique for this study because the photographic records were organised in different groups (= stations).

Table 1. Landscape pattern indices used to quantify spatial patterns of photographs $\left(1 \mathrm{~m}^{2}\right)$ of an undisturbed Antarctic benthic assemblage (southeastern Weddell Sea). The entire set of indices was calculated by Fragstats v3.0 for Arc/Info at landscape level except PERIAREA index, which was calculated from patch data level. Acronyms correspond to those used in Fragstats; see McGarigal \& Marks (1995) for a complete description and definition of each index

\begin{tabular}{|c|c|c|}
\hline Abbreviation & Index name (units) & Description \\
\hline $\mathrm{CA}$ & Cover Area (\%) & Patch coverage \\
\hline \multicolumn{2}{|c|}{ Patch size and variability indices } & Landscape configuration \\
\hline MPS & Mean patch size $\left(\mathrm{cm}^{2}\right)$ & Mean size of patch. MPS $>0$ \\
\hline PSSD & Patch size standard deviation $\left(\mathrm{cm}^{2}\right)$ & Absolute measure of patch size variability. PSSD $\geq 0$ \\
\hline PSCV & Patch size coefficient of variation (\%) & Relative measure of patch size variability. PSCV $\geq 0$ \\
\hline NP & Number of patches & Number of patches. NP $\geq 1$ \\
\hline $\mathrm{TE}$ & Total edge $(\mathrm{cm})$ & Total length of edge involving all landscape patches. TE $\geq 0$ \\
\hline Patch shape indices & & Landscape configuration in terms of complexity \\
\hline MSI & Mean shape index & $\begin{array}{l}\text { Mean patch shape complexity; equals } 1 \text { when all patches are } \\
\text { circular and increases as patches become noncircular. MSI } \geq 1\end{array}$ \\
\hline AWMSI & Area weighted mean shape index & Similar to MSI, but weighted by patch area. AWMSI $\geq 1$ \\
\hline LSI & Landscape shape index & $\begin{array}{l}\text { Perimeter-to-area-ratio for the landscape as a whole, equals } 1 \\
\text { when the landscape consists of a single circular patch and } \\
\text { increases as landscape shape becomes noncircular and the } \\
\text { amount of internal edge increases. LSI } \geq 1\end{array}$ \\
\hline PERIAREA & Mean perimeter to area ratio & Perimeter-to-area-ratio for all landscape patches. PERIARE $>0$ \\
\hline Diversity indices & & Landscape composition \\
\hline SHDI & Shannon's diversity index & $\begin{array}{l}\text { Function between number of different patches and their } \\
\text { abundance. SHDI } \geq 0\end{array}$ \\
\hline SIDI & Simpson's diversity index & $\begin{array}{l}\text { Calculates the proportion of patches in the different patch } \\
\text { types. } 0 \leq \text { SIDI } \leq 1\end{array}$ \\
\hline MISDI & Modified Simpson's diversity index & $\begin{array}{l}\text { Same as Simpson's diversity Index with logarithmic transforma- } \\
\text { tion. MSDI } \geq 0\end{array}$ \\
\hline SHEI & Shannon's evenness index & $\begin{array}{l}\text { Function between the proportional abundance of each patch } \\
\text { type and the number of patch types. } 0 \leq \text { SHEI } \leq 1\end{array}$ \\
\hline SIEI & Simpson's evenness index & $\begin{array}{l}\text { Same as SHEI but calculated using Simpson's diversity index. } \\
0 \leq \mathrm{SIEI} \leq 1\end{array}$ \\
\hline PR & Patch richness & Measures the number of patch types. $P R \geq 1$ \\
\hline Interspersion indices & & Landscape configuration \\
\hline IJI & $\begin{array}{l}\text { Interspersion and } \\
\text { juxtaposition index (\%) }\end{array}$ & $\begin{array}{l}\text { Measures the extension to which each patch type is } \\
\text { interspersed with all other landscape patch types. } 0 \leq \mathrm{IJI} \leq 100\end{array}$ \\
\hline
\end{tabular}


There was relatively strong redundancy among some of the LPI (see Table 1 for abbreviations used from this point): notably, SHDI and SIDI (correlation = 0.94), SHDI and MSIDI (0.97), and SHEI and SIEI (0.77). Therefore, SIDI, MSIDI, and SIEI were not used in the CVA.

Secondly, forward stepwise selection was used to choose a subset of LPI (Legendre \& Legendre 1998). This procedure has the ability to select a reduced group of the explanatory variables, which has the power to discriminate among the whole data set. At each step, the analysis reviews all the variables and includes those, which contribute most to the discrimination. Monte Carlo permutation test (ter Baak 1995) using 199 random permutations was performed to test the significance of the LPI.

Thirdly, principal component analysis (PCA) was carried out to represent relationships among the subset of indices selected.

After these analyses, univariate statistics (ANOVA) were used to test for differences in the subset of LPI among stations to elucidate trends in spatial pattern characteristics. Post hoc comparisons of means were performed using Tukey's tests (Sokal \& Rohlf 1981).

Prior to statistical analyses the data were standardised to ensure that (1) all the indices have equal weight, and (2) they followed a normal distribution in the multivariate analyses. The standardized indices were calculated separately by each raw score (each index per photo) minus the group (= station) mean and divided by the standard deviation of the group (= station). The various ordination techniques and tests were carried out using the programs STATISTICA (Version 5.5, StatSoft) and CANOCO (Version 4, ter Braak \& Smilauer 1998).

\section{RESULTS}

Table 2 shows the values of the 17 LPI calculated for 42 images from 6 stations. It includes means and standard deviations at landscape level.

\section{Ordination and selection analyses}

CVA illustrates the ordination trend of benthic spatial patterns based on LPI among stations. The analysis arranges the photographic samples on the first (A1) and second (A2) axes, respectively (Fig. 3). The first 2 axes accounted for $81 \%$ of the total variation of the data set. The most distinct groups occurred between Stn 211 and the rest of stations, which were ordered along A2. A discontinuity along this axis separated Stn 221 from Stns 008, 042, 215, and 242. Each axis is interpreted ecologically from the correlation between the axes and each of the LPI variables (Table 3). Patch richness $(r=0.61)$ was the predominant variable in A1. Shannon's diversity index (0.43), mean patch size $(-0.38)$, and the interspersion and juxtaposition index (0.35) were also important. Conceptually, these variables describe a gradient from stations with higher patch diversity and interspersion values and lower mean patch size on one extreme, to stations with opposite values, on the other. Four variables characterised A2: percent cover area (-0.52), interspersion and juxtaposition index $(-0.45)$, landscape shape index $(-0.45)$, and total edge $(-0.44)$. The separation of the stations on this axis followed a gradient from higher values of cover area, patch interspersion and juxtaposition, shape complexity, and total edge at one extreme, to lower values of these indices at the other.

Table 2. Means \pm standard deviations of landscape pattern indices from 42 images ( $\mathrm{n}=7$ per station). See Table 1 for abbreviations

\begin{tabular}{|c|c|c|c|c|c|c|}
\hline Landscape indices & Stn 008 & Stn 042 & Stn 211 & Stn 215 & Stn 221 & Stn 242 \\
\hline CA (\%) & $83.5 \pm 8.5$ & $21.2 \pm 7.8$ & $44.3 \pm 24.5$ & $76.3 \pm 8.7$ & $29.9 \pm 8.1$ & $59.5 \pm 27.5$ \\
\hline $\operatorname{MPS}\left(\mathrm{cm}^{2}\right)$ & $43.6 \pm 8.9$ & $22.7 \pm 12.9$ & $115.2 \pm 45.7$ & $65.8 \pm 14.3$ & $26.2 \pm 5.37$ & $41.8 \pm 13.4$ \\
\hline $\operatorname{PSSD}\left(\mathrm{cm}^{2}\right)$ & $209.4 \pm 108.2$ & $51.4 \pm 33.2$ & $128.1 \pm 60.2$ & $174.6 \pm 67.5$ & $51.2 \pm 17.6$ & $151.2 \pm 113.8$ \\
\hline $\operatorname{PSCV}(\%)$ & $468.9 \pm 176.9$ & $228.6 \pm 93.1$ & $115.6 \pm 45.3$ & $258.5 \pm 54.5$ & $192.2 \pm 41.8$ & $338.5 \pm 172.8$ \\
\hline NP & $187.7 \pm 49.8$ & $94.5 \pm 29.7$ & $32.4 \pm 6.2$ & $110.5 \pm 21.1$ & $106.1 \pm 20.6$ & $132.7 \pm 60.3$ \\
\hline $\mathrm{TE}(\mathrm{cm})$ & $2520.1 \pm 375.1$ & $1188.2 \pm 185.2$ & $974.9 \pm 150.3$ & $1919.5 \pm 164.3$ & $1575.1 \pm 267.3$ & $1923.2 \pm 649.3$ \\
\hline MSI & $1.35 \pm 0.02$ & $1.20 \pm 0.03$ & $1.17 \pm 0.07$ & $1.32 \pm 0.06$ & $1.25 \pm 0.02$ & $1.29 \pm 0.10$ \\
\hline AWMSI & $3.26 \pm 1.18$ & $1.47 \pm 0.50$ & $1.15 \pm 0.12$ & $1.95 \pm 0.46$ & $1.61 \pm 0.18$ & $2.44 \pm 1.38$ \\
\hline LSI & $7.47 \pm 1.09$ & $3.54 \pm 0.54$ & $2.88 \pm 0.44$ & $5.63 \pm 0.48$ & $4.63 \pm 0.80$ & $5.69 \pm 1.88$ \\
\hline PERIAREA & $2.07 \pm 0.23$ & $2.78 \pm 1.00$ & $0.81 \pm 0.29$ & $1.77 \pm 0.14$ & $1.61 \pm 0.14$ & $2.23 \pm 0.64$ \\
\hline SHDI & $2.51 \pm 0.26$ & $2.29 \pm 0.24$ & $1.48 \pm 0.63$ & $2.55 \pm 0.18$ & $3.22 \pm 0.11$ & $2.72 \pm 0.31$ \\
\hline SIDI & $0.85 \pm 0.04$ & $0.82 \pm 0.05$ & $0.61 \pm 0.21$ & $0.88 \pm 0.03$ & $0.94 \pm 0.01$ & $0.87 \pm 0.06$ \\
\hline MISDI & $1.95 \pm 0.33$ & $1.78 \pm 0.32$ & $1.11 \pm 0.69$ & $2.19 \pm 0.25$ & $2.95 \pm 0.15$ & $2.15 \pm 0.5$ \\
\hline SHEI & $0.74 \pm 0.06$ & $0.76 \pm 0.07$ & $0.64 \pm 0.18$ & $0.80 \pm 0.05$ & $0.90 \pm 0.01$ & $0.79 \pm 0.09$ \\
\hline SIEI & $0.88 \pm 0.04$ & $0.86 \pm 0.06$ & $0.66 \pm 0.25$ & $0.92 \pm 0.03$ & $0.95 \pm 0.01$ & $0.90 \pm 0.05$ \\
\hline PR & $29.8 \pm 4.5$ & $20.7 \pm 3.3$ & $9.4 \pm 4.4$ & $23.1 \pm 1.6$ & $35.0 \pm 3.8$ & $30.3 \pm 3.7$ \\
\hline IJI (\%) & $65.3 \pm 4.4$ & $53.3 \pm 4.1$ & $38.0 \pm 8.7$ & $63.8 \pm 4.8$ & $55.7 \pm 4.1$ & $54.4 \pm 5.2$ \\
\hline
\end{tabular}




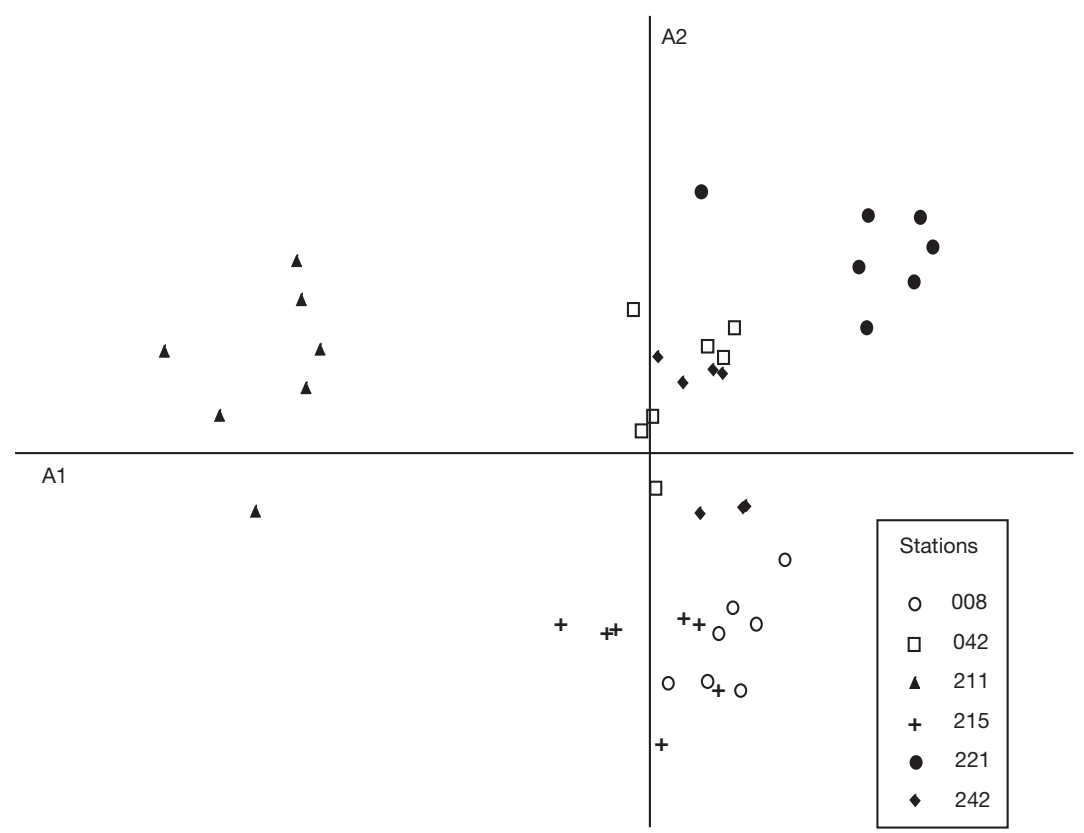

Fig. 3. Canonical variate analysis (CVA) defined by the 2 first axes $(81 \%$ of the total variability) based on LPI for the 6 stations. Each point corresponds to one photograph analysed
In summary, the ordination of photographs over the plane defined an arrangement of an undisturbed benthic assemblage along A1 according to a size and diversity gradient, and A2 according to a cover area, adjacency, and shape complexity gradient.

Forward stepwise procedure was carried out to choose a subset of indices, which best discriminate across stations. Table 4 provides the entry order into the model and the significance for each index. The significant indices $(\mathrm{p}<0.05)$ were MPS, PSCV, PR, IJI, MSI, SHEI, and PERIAREA. These indices were very similar to the predominant indices already described for $\mathrm{A} 1$ and $\mathrm{A} 2$, suggesting that this subset is appropriate for data interpreting. Then, this subset of indices was considered as the optimal for the description of spatial patterns of Antarctic benthos. CVA was repeated using the selected subset of indices. The resulting 2 first axes explained $80 \%$ of the variance and the ordination diagram (not shown) revealed the same general pattern of station distributions as in Fig. 3.

Table 3. (a) Result of canonical variate analysis CVA performed for the photographs on the 14 landscape pattern indices (LPI) observed. (b) Correlation coefficients between LPI and the canonical axes. See Table 1 for abbreviations; ${ }^{* * *} \mathrm{p}<0.001$

\begin{tabular}{|lcc|}
\hline Information & A1 & A2 \\
\hline (a) & & \\
Eigenvalue & 14.18 & 6.46 \\
$\chi^{2}$ test & $229.4^{* * *}$ & $146.7^{* * *}$ \\
Degrees of freedom & 65 & 48 \\
Cumulative percentage of variance & 56 & 81 \\
& & \\
(b) & & \\
Variables: & & \\
CA & 0.01 & -0.52 \\
MPS & -0.38 & -0.08 \\
PSSD & -0.04 & -0.29 \\
PSCV & 0.14 & -0.28 \\
NP & 0.26 & -0.30 \\
TE & 0.23 & -0.44 \\
MSI & 0.18 & -0.33 \\
AWMSI & 0.11 & -0.24 \\
LSI & 0.24 & -0.45 \\
PERIAREA & & \\
SHDI & 0.21 & -0.08 \\
SHEI & 0.43 & 0.06 \\
PR & 0.20 & 0.15 \\
IJI & 0.61 & -0.01 \\
& 0.35 & -0.45 \\
\hline
\end{tabular}

PCA was performed to explore relationships between the subset of indices (Fig. 4). Each index had a correlation $<0.75$ with any other indices selected, indicating no redundancy among them. The first 3 factors

Table 4. Summary of forward stepwise selection from landscape patterns indices (LPI). Monte Carlo permutation test was used to choose a subset of significant indices, which are ordered by decreasing contribution. See Table 1 for abbreviations

\begin{tabular}{|lcc|}
\hline Variables & Step & F to enter/remove \\
\hline MPS & 1 & $6.22^{* *}$ \\
PSCV & 2 & $3.58^{* *}$ \\
PR & 3 & $3.79^{* *}$ \\
IJI & 4 & $2.97^{* *}$ \\
MSI & 5 & $2.64^{* *}$ \\
SHEI & 6 & $2.05^{* *}$ \\
PERIAREA & 7 & $1.72^{* *}$ \\
SHDI & 8 & 1.56 \\
PSSD & 9 & 1.51 \\
TE & 10 & 1.49 \\
AWMSI & 11 & 1.48 \\
LSI & 12 & 1.22 \\
NP & 13 & 1.32 \\
CA & 14 & 0.72 \\
${ }^{* *} p<0.01$, all other values non-significant \\
\hline
\end{tabular}




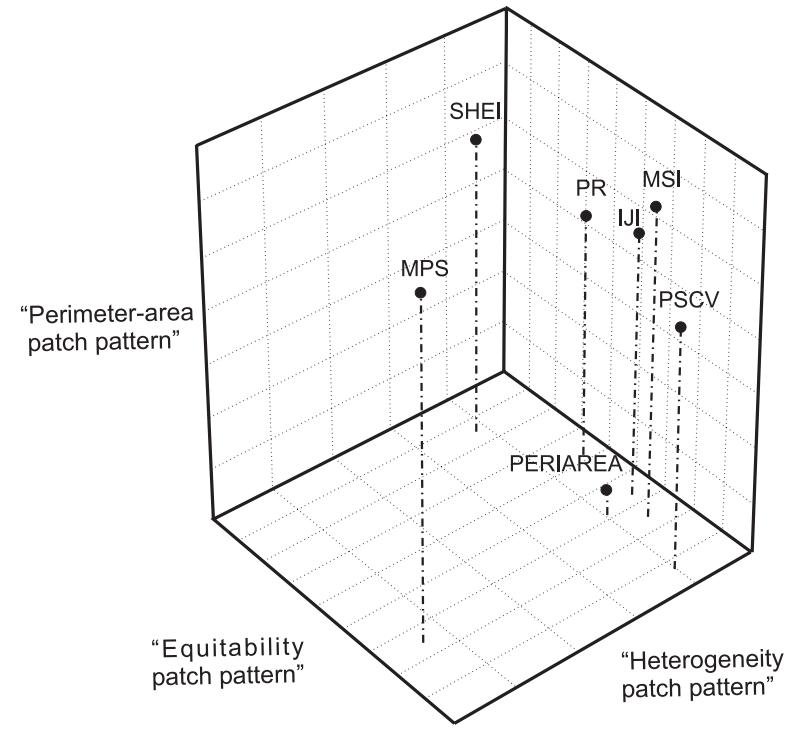

Fig. 4. 3D principal component analysis (PCA) of the subset of indices selected. The 3 first axes account for $84 \%$ of the variance. Mean patch size (MPS), patch size coefficient of variation (PSCV), mean shape index (MSI), periarea index (PERIAREA), Shannon's evenness (SHEI), patch richness (PR), and interspersion and juxtaposition index (IJI)

explained $84 \%$ of the variance. The first factor accounted for $52 \%$ of the variation and discriminated between size (mean patch size) and heterogeneity patterns (patch coefficient of deviation, mean shape index, interspersion and juxtaposition index, and patch richness). It was termed 'heterogeneity patch pattern'. The second factor ( $17 \%$ of the variation) was related to equitability (evenness index) and named 'equitability patch pattern'. The last factor (15\% of the variation) was associated with perimeter-area measures (PERIAREA) leading to the name 'perimeter-area patch pattern'.

\section{Univariate analysis on LPI}

ANOVA was carried out to detect differences among stations based on the values of the selected subset of LPI. There were large differences in LPI among stations (Fig. 5). For better interpretation of the results, diagrammatic representations of the stations and the homogenous groups of LPI means (those that were not significantly different from each other) were performed (Fig. 5). For mean and standard deviation values of LPI see Table 2 .

Patch size and variability indices

MPS and its coefficient of variation (PSCV) showed significant differences in patchiness among stations.
Stn 211 differed significantly from the other stations, having the highest mean value for MPS $\left(115.2 \mathrm{~cm}^{2}\right)$, but the lowest mean value for the PSCV (115.6\%). Large and equal size patches characterized this station (Fig. 5). Stn 215 presented intermediate values for both patch size indices. The rest of stations showed about similar low values for both MPS and PSCV except Stn 008, which had the maximum mean value for PSCV (468.9\%).

Patch shape indices

MSI and PERIAREA showed significant differences among stations by contrasting patch shape complexity (Fig. 5). Both indices indicated similar trends in patch complexity except for Stn 042 (Fig. 5). This station with the largest mean value for PERIAREA (2.78) exhibited relatively low shape complexity for MSI (1.20). The reason for this difference between these shape indices may result from different meaning: PERIAREA index is negatively correlated with patch size and its high values indicate patches with small interior, whereas MSI measures complexity of patch perimeter (Hulshoff 1995). Stn 042 differed significantly from Stns 221 and 215 for PERIAREA (mean ratio values of 1.61 and 1.77, respectively). Stn 008 showed a relatively high mean value for PERIAERA (2.07) and the highest mean value for MSI (1.35), which differed from Stns 042 and 211. Stn 211 had the lowest mean values for both shape indices (1.17 and 0.81 for MSI and PERIAREA, respectively).

\section{Diversity indices}

Diversity indices differed significantly among stations. High values of SHEI result from landscapes where patches are equally distributed among patch types (McGarrigal \& Marks 1995). The least diverse station was Stn 211, with the lowest mean values for PR and SHEI (9.4 and 0.64, respectively), whereas the most diverse station was Stn 221 with the greatest mean values for both diversity indices (35.0 and 0.90 for PR and SHEI) (Fig. 5). Stn 211 was monopolised by few patch categories. Although Stn 008 showed high diversity based on PR (with a mean value of 29.8), it had an intermediate distribution among patch types according to SHEI (mean value of 0.74 ).

\section{Interspersion indices}

Landscapes with high IJI values indicate good interspersion within the patch types (e.g. equally adjacent), 

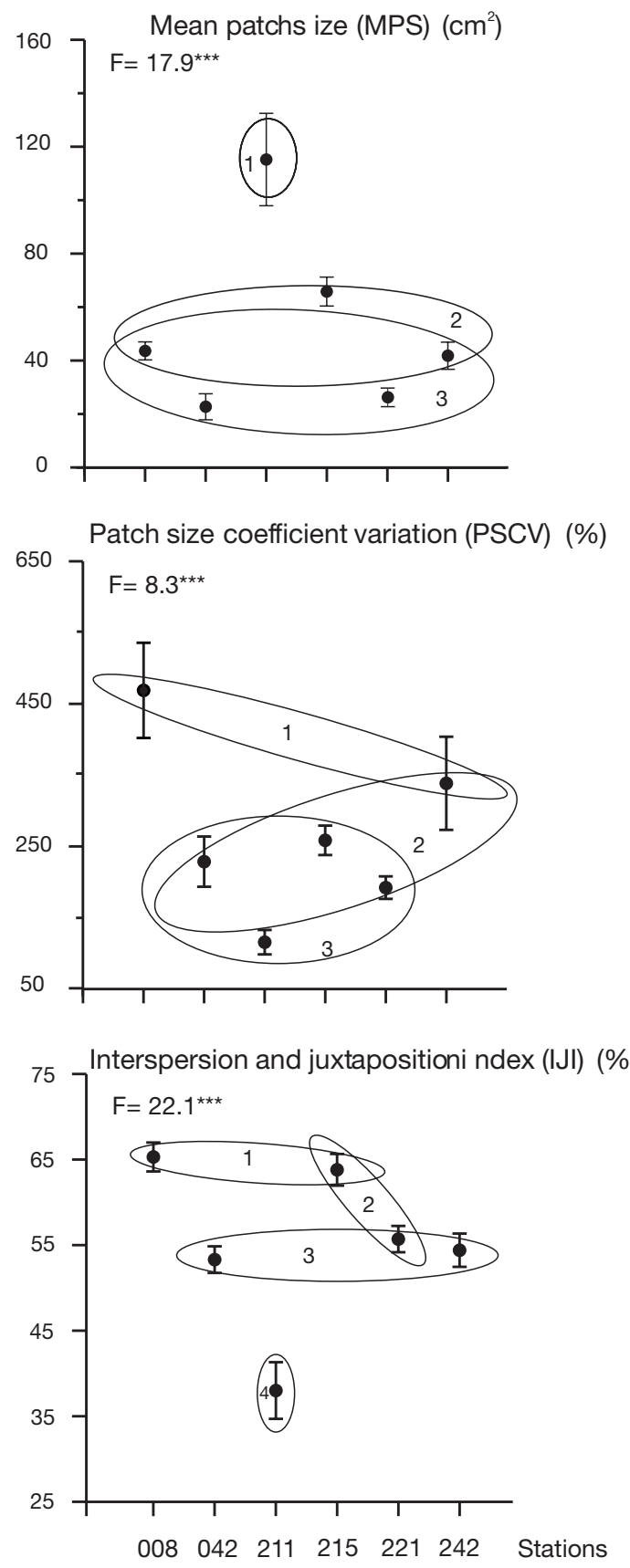

Fig. 5. Representation of 1-way ANOVA analysis (factor: stations) of the subset of landscape pattern indices (LPI). Homogeneous station groups are enclosed with a circle according to Tukey post-hoc multiple comparisons. Data include mean \pm SE. $d f$ effect $=5$, df residual $=36\left({ }^{* * *} \mathrm{p}<0.001\right)$

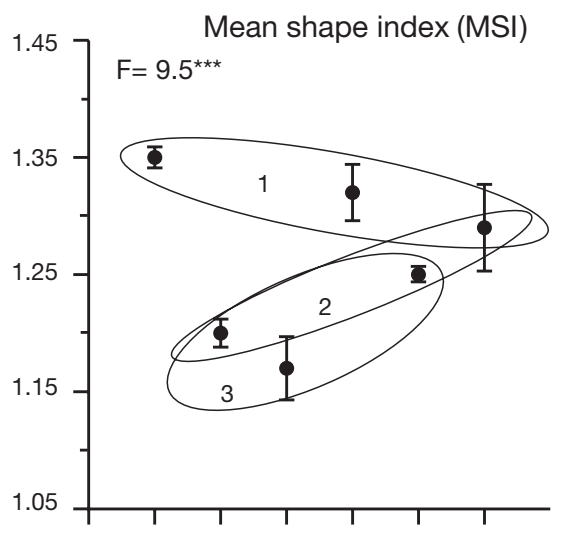

Mean perimeter area ratio (PERIAREA)

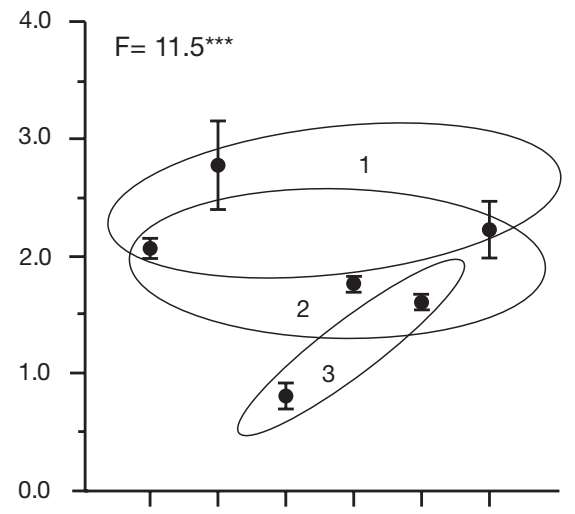

Shannon's evenness index (SHEI)
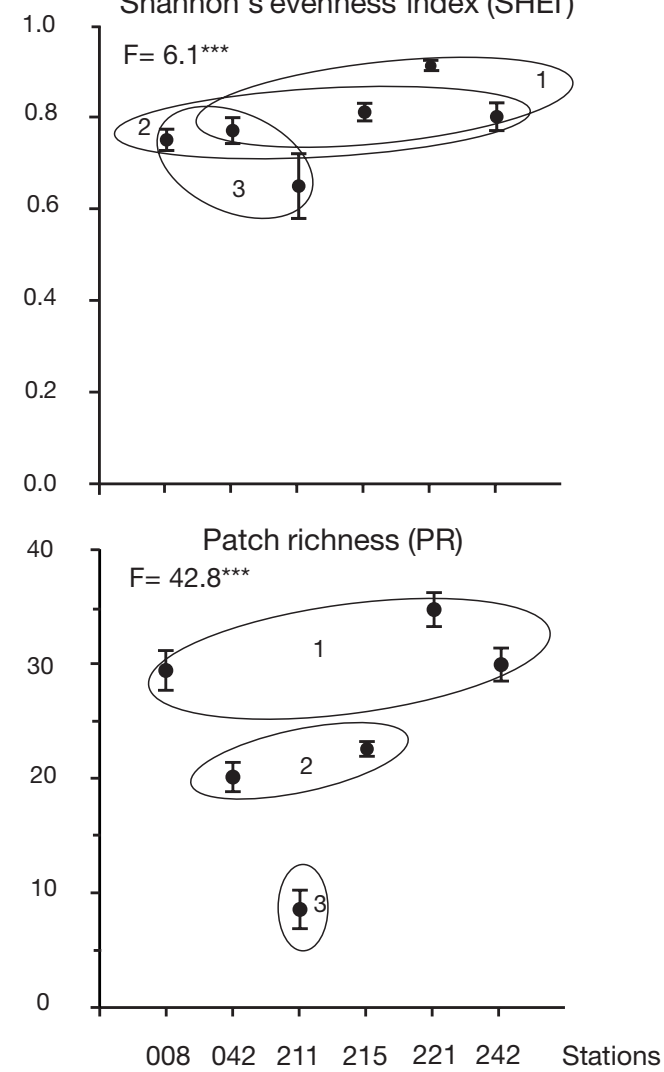
Table 5. Summary of landscape pattern indices (LPI) values selected and the major structural differences among the stations analysed. See Table 1 for abbreviations

\begin{tabular}{|c|c|c|}
\hline Stations & Description of the LPI values & Spatial patterns and cover area \\
\hline 008 and 215 & $\begin{array}{l}\text { Stn } 008 \\
\text { - Medium: MPS, PERIAREA, and SHEI } \\
\text { - High: PSCV, MSI, PR, and IJI } \\
\text { Stn } 215 \\
\text { - Medium: MPS, PSCV, PERIAREA, and PR } \\
\text { - High: MSI, SHEI, and IJI }\end{array}$ & $\begin{array}{l}\text { Highest spatial complexity and intermediate diversity patterns } \\
\text { Different well-mixed groups of benthic sessile organisms } \\
\text { covering completely the sediment exhibited: } \\
\text { - Intermediate but variable patch size } \\
\text { - Complex shapes and patch types high equally adjacent } \\
\text { - Different patch composition and relatively equally distributed }\end{array}$ \\
\hline 242 and 042 & $\begin{array}{l}\text { Stn } 242 \\
\text { - Medium: MPS, PERIAREA and IJI } \\
\text { - High: PSCV, MSI, SHEI, and PR } \\
\text { Stn } 042 \\
\text { - Low: MPS and MSI } \\
\text { - Medium: PSCV, SHEI, PR, and IJI } \\
\text { - High: PERIAREA }\end{array}$ & $\begin{array}{l}\text { Intermediate spatial complexity and diversity patterns } \\
\text { Different well-mixed groups of benthic sessile organisms } \\
\text { covering the major part of the bottom sediment exhibited: } \\
\text { - Intermediate and relatively uniform patch size } \\
\text { - Relative/rather complex shapes and patch types equally adjacent } \\
\text { - Different patch composition and relatively equally distributed }\end{array}$ \\
\hline 221 & $\begin{array}{l}\text { Stn } 221 \\
\text { - Low: MPS and PSCV } \\
\text { - Medium: MSI, PERIAREA, and IJI } \\
\text { - High: SHEI and PR }\end{array}$ & $\begin{array}{l}\text { Intermediate spatial complexity and highest diversity patterns } \\
\text { Different highly-mixed groups of benthic sessile organisms } \\
\text { covering partially the bottom sediment exhibited: } \\
\text { - Relatively small and uniform patch size } \\
\text { - Relatively intermediate complex shapes } \\
\text { - Highly different patch composition and very equally distributed }\end{array}$ \\
\hline Stn 211 & $\begin{array}{l}\text { Stn } 211 \\
\text { - Low: PSCV, MSI, PERIAREA, } \\
\text { SHEI, PR, and IJI } \\
\text { - High: MPS }\end{array}$ & $\begin{array}{l}\text { Low spatial complexity and diversity patterns } \\
\text { Mostly sponges covering partially the bottom sediment exhibited: } \\
\text { - Large and similar patch size } \\
\text { - Low complex shapes } \\
\text { - Few patch types and poorly interspersed among them }\end{array}$ \\
\hline
\end{tabular}

whereas low values characterise landscapes with poorly interspersed patch types (e.g. disproportionate distribution of patch type adjacencies) (McGarrigal \& Marks 1995). Stn 211 showed significant differences from the rest of the stations, having the lowest interspersed patterns among patch types (mean value of $38.0 \%$ ) (Fig. 5). Stns 008 and 215 presented the highest mean IJI values, 65.3 and $63.8 \%$, respectively indicating high interspersed patterns. These stations differed significantly from Stns 042, 221, and 242 (with relatively intermediate IJI mean values of 53.3, 55.7, and $54.4 \%$, respectively).

\section{DISCUSSION}

The application of LPI in this study was useful for characterising spatial patterns of an undisturbed Antarctic benthic assemblage and for showing differences in spatial patterns across stations. The 14 metrics of LPI analysed through the combination of CVA (Fig. 3) and the interpretation of the ANOVA analysis (Fig. 5) revealed a trend of dispersion and significant differences among the stations. Overall, stations differed in size and diversity of patches and in hetero- geneity patterns (size variability, shape, and interspersion of patches). The photographic records analysed only referred to the undisturbed assemblage (characterised by a mixture of sessile suspension feeders) (Gutt \& Starmans 2001) for which minor differences in spatial pattern would be expected. Nevertheless, LPI showed a great discriminatory power detecting significant differences among stations within this assemblage (Figs. $3 \&$ 5). Therefore, the application of LPI to quantify spatial patterns across assemblages (e.g. along depth zonation, across disturbance gradients caused by sewage or iceberg scouring) should result in an excellent discriminatory power. A previous work (Garrabou et al. 1998) was also successful in applying LPI to Mediterranean rocky benthic communities along a depth gradient. The application of this methodology to Antarctic benthos as well as to other benthic communities (from meio to macrobenthos) will increase our understanding of structural patterns and processes in these complex habitats.

Spatial patterns are expressed as several measures of mosaic structure (Table 1), which may be quantified at a particular point of time. The spatial scale of ecological data encompasses both 'grain' (resolution) and 'extent' (total area) (Turner et al. 1989). There is no 
single and correct scale of analysis to investigate a system (Levin 1992). The appropriate scale of observation will depend on the questions asked, the habitat analysed, the organisms studied, and the time periods considered (Wiens 1989). In our study, an increase in the extent $\left(1 \mathrm{~m}^{2}\right)$ would mean a greater sampling area but a decrease of grain (approx. $0.3 \mathrm{~mm}$ ), thus a loss in taxonomic identification (necessary for diversity measurements). For instance, Turner \& Ruscher (1988) reported distinct diversity gradients in the same set of terrestrial landscapes considering both finer and coarser spatial resolution. Therefore, preserving grain and extent is essential for comparative studies.

LPI in the Weddell Sea can only be compared in the case of diversity indices, which had been calculated before using traditional methods (absence/presence) in image techniques. Diversity index values of the present study were slightly higher than those obtained from previous calculations for the same assemblage and depths. Shannon diversity ranged from 1.48 to 3.22 versus 2.3 to 2.5 and evenness from 0.64 to 0.90 versus 0.57 to 0.6, respectively (Table 2) (Gutt \& Starmans 1998, Starmans et al. 1999). We attribute the differences to the higher resolution of the underwater photographs compared to ROV-acquired images and their larger total area sampled.

Our analysis using stepwise selection procedure supports the argument that a subset of indices can capture significant traits of spatial pattern $\left(\mathrm{O}^{\prime}\right.$ Neill et al. 1988, Turner \& Ruscher 1988, Ritters et al. 1995). We considered MPS, PSCV, PR, IJI, MSI, SHEI, and PERIAREA as the optimal subset of LPI to discriminate across the benthic stations (Table 4). The stepwise selection analysis was an appropriate method to select these indices because it ends with a set of metrics, which has the maximal discriminatory value. Our subset of indices differs from those chosen to characterise Mediterranean benthic communities (Garrabou et al. 1998). As in terrestrial ecosystems, there is not an ideal standard subset of indices to describe benthic habitats and each case study should choose the best subset for the spatial patterns quantification.

LPI provided comprehensive measurements over different aspects of spatial patterns (patch size and form, diversity and interspersion) (Table 5, Figs. 3 \& 5). Spatial complexity and diversity patterns of an undisturbed benthic assemblage increased from Stn 211 to the rest of stations. Stn 211 was mostly dominated by volcano-shape hexactinellid sponges and one spherical-shape demosponge species (Cinachyra barbata). Large patches of similar size partially covered and monopolised the substrate. The patches showed less complex shapes, were less diverse, and less interspersed. Stn 008 showed the most complex and relatively diverse pattern, with intermediate but variable patch size. The patches exhibited complex shapes, were highly different in composition, relatively equally distributed, and well interspersed. Heterogeneity patterns (variable patch sizes, patches with complex shapes, and interspersion) decreased from Stn 215 through Stns 242 to 042 . These 3 stations and Stn 008 were composed by different well-mixed groups of benthic sessile organisms (e.g. sponges, gorgonians, bryozoans, and ascidians), which covered the major part of the bottom sediment. The most diverse pattern occurred at Stn 221 characterised by demosponges, gorgonians, and bryozoans, which partially covered the seafloor. However, this station did not show high heterogeneity patterns such as Stns 008, 215, and 242. Based on LPI values of this study, spatial patterns and diversity did not converge toward a particular scenario. On the contrary, LPI results suggest a separation between rich and diverse stations, which partially covered the seafloor and those with high values of pattern heterogeneity (highest patchiness, form complexity, and interspersion). These differences within the undisturbed assemblage show the importance of quantification of different aspects of spatial patterns (diversity alone did not discern among all stations).

Overall, Antarctic benthos is influenced by different combination and intensity of biotic (predation, competition, recruitment) (Arntz et al. 1994, Clarke 1996) and abiotic factors (substratum, sedimentation, currentsfood supply, ice scouring, depth) (Dayton et al. 1970, 1994, Gallardo 1987, Barnes et al. 1996), which might explain the different spatial pattern trends obtained through the quantification of LPI. For example, epibiotic relationships are considered as an important factor structuring Antarctic benthic communities (Dayton et al. 1970, Gutt \& Schickan 1998) since these relationships contribute to the development of the diverse 'multi-storeyed assemblages'. Barthel (1992) and Kunzmann (1996) demonstrated the role of sponges as substrata for other invertebrates. Our results showed the lowest diversity values in situations where sponges were the dominant group (Stn 211) and intermediate values when sponges did not monopolise the space (Stn 042) (Figs. 3 \& 5). Most of the epifauna found on the Cinachyra barbata (demosponge) and hexactinellid sponges with smooth surface (Rossella nuda and Scolymastra joubini) were motil organisms (not included for LPI calculations, see 'Material and methods') and there were few sessile epibenthic organisms (Stn 211). In contrast, Stn 042 exhibited some hexactinellid sponges with superficial spicules $(R$. antarctica and $R$. racovitzae) that allowed the development of a variety of sessile organisms (hydrozoans, demosponges, bryozoans, polychaetes, ascidians, and holothurians). The other stations (Stns 008, 215, 221, and 242) also showed epibiothic relationships but the sub- 
strata were other sessile organisms (mainly demosponges, gorgonians, and ascidians). Kunzmann (1996) remarked the difference of the hexactinellid's surface (with and without surface spicules) for the development of epibenthic associated fauna. Our results agree with her observation and may be that biochemical composition (McClintock 1987) of C. barbata and hexactinellid sponges with smooth surface do not favour the settlement of sessile epibenthic organisms on their surface and in their surroundings. This phenomenon may partly be an explanation of the significant differences in diversity within the undisturbed assemblage.

Several studies in the Weddell Sea (Gutt \& Piepenburg 1991, Gutt \& Koltun 1995, Starmans et al. 1999) described a high degree of patchiness in spatial distribution patterns of benthic communities. Sponge patchiness at a small scale, which was also observed in our study, could result from biological characteristics of single species (Gutt \& Koltun 1995). Stn 211 exhibited the lowest value of IJI providing insights for strong interespecific competitive interactions (degree of species adjacencies in relation to their cover) (Turon et al. 1996) or success of species with very low dispersal of sexual and/or asexual recruits in the communities (Wulff 1991). Similar observations of aggregations of sponges were reported for Cinachyra barbata (Barthel \& Gutt 1992) and Rossella racovitzae with a budding asexual reproductive mode (Dayton 1979).

The application of LPI showed relevant information to characterise the spatial organization within the undisturbed assemblage. Moreover, LPI provided some insights in the ecological factors that may be responsible for the patterns observed. These interpretations could be specifically tested by ecological data on the natural history of species and using adequate experimental designs whenever possible (Dayton \& Sala 2001).

\section{CONCLUSIONS}

The successful description of Antarctic benthic communities through landscape pattern indices provides a useful tool for the characterisation and comparison of spatial patterns in marine benthic habitats. Our results also suggest that a subset of indices captures significant traits to obtain a comprehensive description of landscape spatial pattern.

Acknowledgements. We thank P. López (gorgonians), M. Zabala (bryozoans), A. Ramos (ascidians), and M. C. Gambi (polychaetes) for taxonomic assistance. D. Piepenburg facilitated his photographic material from Stns 042 and 211 (ANT XV/III). Special thanks are due to W. Wosniok and T. Arcas for their statistical support, J. Cowardin for his technical assistance with the FRAGSTATS software, and J. Riera for his help in the image analysis. Critical comments of J. Gutt are greatly acknowledged. The manuscript improved after the comments of A. Clarke and 2 anonymous referees. This study was partially funded by DAAD (A/99/13106) and Bremen University. J.G. was funded by a Marie Curie Fellowship HPMF-CT1999-00202.

\section{LITERATURE CITED}

Arnaud PM (1974) Contribution à la bionomie marine benthique des régions antarctiques et subantarctiques. Tethys 6:465-656

Arnaud PM (1977) Adaptations within the Antarctic marine benthic ecosystem. In: Llano GA (ed) Adaptations within Antarctic ecosystems. Smithsonian Institution, Washington, DC, $\mathrm{p}$ 135-157

Arntz WE, Gutt J (1997) The expedition ANTARKTIS XIII/3 (EASIZ I) of RV 'Polarstern' to the eastern Weddell Sea in 1996. Ber Polarforsch 249:1-148

Arntz WE, Gutt J (1999) The expedition ANTARKTIS XV/3 (EASIZ II) of RV 'Polarstern' to the eastern Weddell Sea in 1998. Ber Polarforsch 301:1-229

Arntz WE, Brey T, Gallardo VA (1994) Antarctic zoobenthos. Oceanogr Mar Biol Annu Rev 32:241-304

Barnes DKA (1995) Sublittoral epifaunal communities at Signy Island, Antarctica. II. Below the ice-foot zone. Mar Biol 121:565-572

Barnes DKA, Clarke A, Rothery P (1996) Colonisation and development of encrusting communities from the Antarctic intertidal and sublittoral. J Exp Mar Biol Ecol 196:251-265

Barthel D (1992) Antarctic hexactinellids: a taxonomically difficult, but ecologically important benthic component. Verhandlungen der Deutschen Zoologischen Gesellschaft 85(2):271-276

Barthel D, Gutt J (1992) Sponge associations in the eastern Weddell Sea. Antarct Sci 4(2):137-150

Bathmann U, Fischer G, Müller PJ, Gerdes D (1991) Shortterm variations in particulate matter sedimentation off Kapp Norvegia, Weddell Sea, Antarctica: relation to water mass advection, ice cover, plankton biomass and feeding activity. Polar Biol 11:185-195

Bullivant JS (1967) Ecology of the Ross Sea benthos. Bulletin of the New Zealand Department of Scientific and Industrial Research 176:49-78

Cain DH, Ritters K, Orvis K (1997) A multi-scale analysis of landscape statistics. Landsc Ecol 12:199-212

Carmack EC, Foster TD (1977) Water masses and circulation in the Weddell Sea. In: Dunbar MJ, Alberta C (eds) Polar oceans: Proc Polar Oceans Conf, May 1974. Arctic Institute of North America, Montreal, p 167-177

Clarke A (1996) Marine benthic populations in Antarctica: patterns and processes. In: Ross RM, Hofmann EE, Quetin LB (eds) Foundations for ecological research west of the Antarctic Peninsula. American Geophysical Union, Ant Res Ser 70:373-388

Dayton PK (1979) Observations of growth, dispersal and population dynamics of some sponges in McMurdo Sound, Antarctica. Colloq Int Cons Natl Rech Sci 291:271-282

Dayton PK (1990) Polar benthos. In: Smith WO (ed) Polar oceanography, Part B: chemistry, biology, and geology. Academic Press, London, p 631-685

Dayton PK, Sala E (2001) Natural history: the sense of wonder, creativity and progress in ecology. Sci Mar 65(2):199-206

Dayton PK, Robilliard GA, Paine RT (1970) Benthic faunal 
zonation as a result of anchor ice at McMurdo Sound, Antarctica. In: Holdgate MW (ed) Antarctic ecology. Academic Press, New York, p 244-258

Dayton PK, Mordida BJ, Bacon F (1994) Polar marine communities. Am Zool 34:90-99

Dell RK (1972) Antarctic benthos. Adv Mar Biol 10:1-216

Discovery Committee Colonial Office (1929-1980) Discovery Reports, Vol. 1-37. Cambridge University Press, Cambridge

Drapeau P, Leduc A, Giroux J, Savard J, Bergeron Y, Vickery W (2000) Landscape-scale disturbances and changes in bird communities of boreal mixed-wood forests. Ecol Monogr 70(3):423-444

Dunbar RB, Anderson JB, Domack, EW (1985) Oceanographic influence on sedimentation along the Antarctic continental shelf. Ant Res Ser 43:291-312

Fahrbach E, Rohardt G, Krause G (1992) The Antarctic Coastal Current in the southeastern Weddell Sea. Polar Biol 12:171-182

Forman RTT, Gordon M (1986) Landscape ecology. Wiley, New York

Gallardo VA (1987) The sublittoral macrofaunal benthos of the Antarctic shelf. Environ Int 13:71-81

Gambi MC, Lorenti M, Giovanni FR, Scipione, MB (1994) Benthic associations of the shallow hard bottoms off Terra Nova Bay, Ross Sea: zonation, biomass and population structure. Antarct Sci 6(4):449-462

Garrabou J, Riera J, Zabala M (1998) Landscape pattern indices applied to Mediterranean subtidal rocky benthic communities. Lands Ecol 13:225-247

Garrabou J, Ballesteros E, Zabala M (in press) Structure and dynamics of north-western Mediterranean rocky benthic communities along a depth gradient. Estuar Coast Shelf Sci

Gerdes D, Klages M, Arntz WE, Herman RL, Galerón J, Hain S (1992) Quantitative investigation on macrobenthios communities of the southeastern Weddell Sea shelf based on multibox corer samples. Polar Biol 12:291-301

Gleitz M, Bathmann U, Lochte K (1994) Build-up and decline of summer phytoplankton biomass in the eastern Weddell Sea, Antarctica. Polar Biol 14:413-422

Gruzov YN, Propp MV, Pushkin AF (1968) Biological associations of costal areas of the Davis Sea (based on the observations of divers). Soviet Antarct Exped Inf Bull 6(6): $523-533$

Gutt J (2000) Some 'driving forces' structuring communities of the sublittoral Antarctic macrobenthos. Antarct Sci 12(3): 297-313

Gutt J, Koltun V (1995) Sponges of the Lazarev and the Weddell Sea, Antarctica: explanations for their patchy occurrence. Antarct Sci 7(3):227-234

Gutt J, Piepenburg D (1991) Dense aggregations of three deep-sea holothurians in the southern Weddell Sea, Antarctica. Mar Ecol Prog Ser 68:277-285

Gutt J, Schickan T (1998) Epibiotic relationships in Antarctic benthos. Antarct Sci 10(4):398-405

Gutt J, Starmans A (1998) Structure and biodiversity of megabenthos in the Weddell and Lazarev Seas (Antarctica): ecological role of physical parameters and biological interactions. Polar Biol 20:229-247

Gutt J, Starmans A (2001) Quantification of iceberg impact and benthic recolonisation patterns in the Weddell Sea (Antarctica). Polar Biol 24:615-619

Gutt J, Starmans A, Dieckmann G (1996) Impact of iceberg scouring on polar benthic habitats. Mar Ecol Prog Ser 137: $311-316$

Hargis CD, Bissonette JLD (1998) The behavior of landscape metrics commonly used in the study of habitat fragmentation. Lands Ecol 13(3):167-186

Hayward PJ (1995) Antarctic cheilostomatous Bryozoa. Oxford University Press, Oxford

Hedgpeth JW (1969) Introduction to Antarctic zoogeography. In: Bushnell V, Hedgpeth JW (eds) Distribution of selected groups of marine invertebrates in waters south of $35^{\circ}$ latitude. Antarctic Map Folio Series 11. American Geographical Society, New York, p 1-9

Hedgpeth JW (1971) Perspectives in benthic ecology in Antarctica. In: Quam LO (ed) Research in the Antarctic. Am Assoc Adv Sci, Washington DC, p 667-684

Hempel G (1985) On the biology of polar seas, particularly the Southern Ocean. In: Gray JS, Christiansen ME (eds) Marine biology of polar regions and effects of stress on marine organisms. Wiley, Chichester, p 3-31

Hulshoff RM (1995) Landscape indices describing a Dutch landscape. Lands Ecol 10(2):101-111

Kirkwood JM, Burton HR (1988) Macrobenthic species assemblages in Ellis Fjord, Vestfold Hills, Antarctica. Mar Biol 97:445-457

Kineast F (1993) Analysis of historic landscape patterns with a Geographical Information System-a methodological outline. Lands Ecol 8(2):103-118

Knox GA (1960) Littoral ecology and biogeography of the southern ocean. Proc R Soc Lond B152:577-625

Knox GA (1994) The biology of the Southern Ocean. Cambridge University Press, Cambridge

Knox GA, Lowry JK (1977) A comparison between the benthos of the Southern Ocean and the North Polar Ocean with special reference to the Amphipoda and Polychaeta. In: Dunbar MJ (ed) Polar oceans. Arctic Institute of North America, Montreal, p 423-462

Kunzmann K (1996) Associated fauna of selected sponges (Hexactinellida and Demospongiae) from the Weddell Sea, Antarctica. Ber Polarforsch 210:1-93

Legendre P, Legendre L (1998) Numerical ecology. Developments in environmental modelling; 20. Elsevier, Amsterdam

Levin S (1992) The problem of pattern and scale in ecology. Ecology 73(6):1943-1967

McClintock JB (1987) Investigation on the relationship between invertebrate predation and biochemical composition, energy content, spicule armament and toxicity of benthic sponges at McMurdo Sound, Antarctica. Mar Biol 94:479-487

McGarigal K, Marks BJ (1995) FRAGSTATS: spatial pattern analysis program for quantifying landscape structure. Program documentation. Gen Tech Rep US Dep Agric For Serv Pac Northwest Res Stn 351, Portland

McGarrigal K, McComb WC (1995) Relationships between landscape structure and breeding birds in the Oregon coastal range. Ecol Monogr 65(3):235-260

Monniot C, Monniot F (1983) Ascidies antarctiques et subantarctiques: morphologie et biogéographie. Mem Mus Nat Hist Nat Nouv Ser A 125:1-168

Nelson DM, Smith WO Jr, Muench RD, Gordon LI, Sullivant CW, Husby DM (1989) Particulate matter and nutrient distributions in the ice-edge zone of the Weddell Sea: relationship to hydrography during the late summer. Deep-Sea Res 36:191-209

O'Neill RV, Krummel JR, Gardner RH, Sugihara G, Jackson B, DeAngelis DL, Milne BT, Turner MG, Zygmunt B, Christensen SW, Dale VH, Graham RL (1988) Indices of landscape pattern. Landsc Ecol 1:153-162

Park MG, Yang SR, Kang SH, Chung KH, Shim JH (1999) Phytoplankton biomass and primary production in the 
marginal ice zone of the northwestern Weddell Sea during austral summer. Polar Biol 21:251-261

Peck L, Brockington S, Vanhove S, Beghyn M (1999) Community recovery following catastrophic iceberg impacts in a soft-sediment shallow-water site at Signy Island, Antarctica. Mar Ecol Prog Ser 186:1-8

Riitters KH, O'Niell RV, Hunsaker CT, Wickham DH, Yankee DH, Timmins SP, Jones KB, Jackson BL (1995) A factor analysis of landscape pattern and structure metrics. Lands Ecol 10(1):23-39

Sarà A, Balduzzi A, Barbieri M, Bavestrello G, Burlando B (1992) Biogeographic traits and checklist of Antarctic demosponges. Polar Biol 12:559-585

Saunders S, Chen J, Crow TR, Brosofske KD (1998) Hierarchical relationships between landscape structure and temperature in a managed forest landscape. Lands Ecol 13: 381-395

Sieg J, Wägele JW (1990) Fauna der Antarktis. Parey, Berlin

Sokal RR, Rohlf FJ (1981) Biometry: the principles and practice of statistics in biological research. Freeman, San Francisco

Starmans A, Gutt J (2002) Mega-epibenthic diversity: a polar comparison. Mar Ecol Prog Ser 225:45-52

Starmans A, Gutt J, Arntz WE (1999) Mega-epibenthic communities in Antarctic and Arctic shelf areas. Mar Biol 135: 269-280

StatSoft (2000) STATISTICA for Windows. Computer program manual. Statsoft, Tulsa

Thompson CW, Murray J (1880-1889) Report on the scientific results of the voyage of HMS Challenger during the years 1873-760. Zoology, Vol. 1-32, Neill, Edinburgh

ter Braak CJF (1995) Ordination. In: Jongman RHG, ter Braak

Editorial responsibility: Otto Kinne (Editor),

Oldendorf/Luhe, Germany
CJF, van Tongeren OFR (eds) Data analysis in community and landscape ecology. Cambridge University Press, Cambridge, p 91-169

ter Braak CJF, Smilauer P (1998) CANOCO Reference manual and user's guide to Canoco for Windows (Version 4). Microcomputer Power, Ithaca

Tréguer P, Jacques G (1992) Dynamics of nutrients and phytoplankton, and fluxes of carbon, nitrogen and silicon in the Antarctic Ocean. Polar Biol 12:149-162

Turner MG (1989) Landscape ecology: the effect of pattern on process. Annu Rev Ecol Syst 20:171-197

Turner MG, Ruscher CL (1988) Changes in landscape patterns in Georgia, USA. Lands Ecol 1(4):241-251

Turner MG, O'Neill RV, Gardner RH, Milne BT (1989) Effects of changing spatial scale on the analysis of landscape pattern. Lands Ecol (3-4):153-162

Turon X, Bacerro MA, Uriz MJ, Llopis J (1996) Small-scale association measures in epibenthic communities as a clue for allelochemical interactions. Oecologia 108:351-360

Voß J (1988) Zoogeographie und Gemeinschaftsanalyse des Makrozoobenthos des Weddellmeeres (Antarktis). Ber Polarforsch 109:1-145

White MG (1984) Marine benthos. In: Laws RM (ed) Antarctic ecology, Vol. 2. Academic Press, London, p 421-461

Wiens JA (1989) Spatial scaling in ecology. Funct Ecol 3: 385-397

Wiens JA, Stenseth NC, van Horne B, Ims RA (1993) Ecological mechanisms and landscape ecology. Oikos 66: $369-380$

Wulff JL (1991) Asexual fragmentation, genotype success, and population dynamics of erect branching sponges. J Exp Mar Biol Ecol 149:227-247

Submitted: March 27, 2002; Accepted: July 18, 2002

Proofs received from author(s): October 15, 2002 